\title{
Pregnancy Intentions Among Salvadoran Fathers: Results from the 2003 National Male Reproductive Health Survey
}

CONTEXT: In El Salvador, fathers less commonly say that pregnancies are unintended than mothers do. However, men's pregnancy intentions are not understood as well as women's.

METHODS: Data from 425 fathers participating in the 2003 National Male Reproductive Health Survey of El Salvador were analyzed to examine their intentions in regard to partners' pregnancies that had ended in a live birth in the last five years. They were asked whether they had been trying to avoid pregnancy at the time of conception, whether they had been trying to get their partner pregnant, how they had felt about the pregnancy and what they thought their partner's pregnancy intentions had been. Descriptive analyses were based on the most recent pregnancy reported by each man.

RESULTS: A quarter of the pregnancies had been unintended from the men's perspective-13\% had been mistimed and $11 \%$ had been unwanted. Almost half (46\%) of unintended pregnancies had been conceived when the father was trying to avoid pregnancy. However, $36 \%$ of men reporting an unintended pregnancy said they had been happy when they found out about it. For $20 \%$ of all pregnancies, men perceived that their partner's pregnancy intentions differed from their own.

CONCLUSIONS: Family planning services in EI Salvador need improvement, and services and outreach should target men. Men's experiences with unintended pregnancies - in particular, contraceptive failure and discordance within couples about pregnancy intention - are complex and merit further investigation.

International Family Planning Perspectives, 2005, 31(4):179-182
By Marion Carter and llene S. Speizer

At the time this analysis was conducted, Marion Carter was an officer in the Epidemic Intelligence Service, Division of Reproductive Health, Centers for Disease Control and Prevention, Atlanta, GA, USA. Ilene S. Speizer is research associate professor, University of North Carolina at Chapel Hill, Chapel Hill, NC, USA.
Today, national data from men about reproductive health knowledge, attitudes and behavior are available for more than 45 countries, and men are increasingly being included in smaller reproductive health studies. ${ }^{1}$ Data from men are often compared with data from women to identify similarities and differences between the sexes and their group experiences. For example, in 21 of 41 countries with comparable data from the two sexes, married men reported that, on average, they wanted at least 0.5 more children than did married women. ${ }^{2}$ In addition, levels of approval of family planning among married men were often higher than the levels derived from married women's reports about their husbands' attitudes. Such findings stimulate thinking about how men's and women's experiences differ and indicate the need to explore data gathered from men in more depth to understand their reproductive health attitudes and preferences.

Recent companion surveys of nationally representative, independent samples of Salvadoran men and women of reproductive age provide an opportunity to compare pregnancy intentions between sexes. Two types of pregnancies are conventionally categorized as unintended: those that were conceived earlier than was desired (mistimed) and those that were not wanted at the time of conception (unwanted). Unintended pregnancy is important insofar as it reflects an unmet need for family planning and the extent to which women and men have not fulfilled their childbearing goals in terms of freely deciding the number and spacing of their children. ${ }^{3}$ According to the survey of reproductive-age Salvadoran women, conducted in 2002 2003, 58\% of recent pregnancies that ended in live births in the last five years were intended and $42 \%$ were unintended (18\% mistimed and $24 \%$ unwanted). However, in the companion survey of reproductive-age men conducted in $2003,75 \%$ of such pregnancies were intended and $23 \%$ were unintended (12\% mistimed, $11 \%$ unwanted); for the remaining $2 \%$, men's intentions were unknown. ${ }^{4}$ This difference between men and women in reported pregnancy intentions raises many questions about the meaning and measurement of pregnancy desires and intentions in El Salvador, particularly among fathers, who have not often been the subject of studies of unintended pregnancy.

To explore unintended pregnancy among Salvadoran men, we examined additional contextual information about recent pregnancies reported by fathers in the male sample. Specifically, the male survey obtained information on whether men had been trying to avoid pregnancy at the time of conception, whether they had been trying to get their partner pregnant, how they had felt about the pregnancy and what they thought their partner's pregnancy intentions had been. With these data, we explored the potential contribution of contraceptive failure to unintended pregnan- 
TABLE 1. Percentage distribution of men's responses to questions about their partner's most recent pregnancy ending in a live birth, according to intendedness of the pregnancy, El Salvador, 2003

\begin{tabular}{|c|c|c|c|}
\hline Question & $\begin{array}{l}\text { All } \\
(N=425)\end{array}$ & $\begin{array}{l}\text { Intended } \\
(\mathrm{N}=311)^{*}\end{array}$ & $\begin{array}{l}\text { Unintended } \\
(\mathrm{N}=107)^{*}\end{array}$ \\
\hline \multicolumn{4}{|c|}{$\begin{array}{l}\text { When your partner became pregnant with [child's name], did you } \\
\text { want the pregnancy then, want to wait or not want it at all? }\end{array}$} \\
\hline Wanted then (intended) & 74.8 & 100.0 & 0.0 \\
\hline Wanted to wait (mistimed) & 13.3 & 0.0 & 57.9 \\
\hline Did not want at all (unwanted) & 10.5 & 0.0 & 42.1 \\
\hline Don't know/no response & 1.5 & na & na \\
\hline \multicolumn{4}{|c|}{$\begin{array}{l}\text { When your partner became pregnant with [child's name], were you } \\
\text { doing something to avoid pregnancy? }\end{array}$} \\
\hline Yes & 15.9 & 6.7 & 45.5 \\
\hline No & 84.1 & 93.3 & 54.5 \\
\hline \multicolumn{4}{|c|}{$\begin{array}{l}\text { When your partner became pregnant with [child's name], were you } \\
\text { trying to get her pregnant? }\end{array}$} \\
\hline Yes & 71.8 & 92.9 & 7.2 \\
\hline No & 28.2 & 7.1 & 92.8 \\
\hline \multicolumn{4}{|c|}{ When you found out about that pregnancy, how did you feel? +} \\
\hline Happy & 79.8 & 94.4 & 35.9 \\
\hline Surprised & 5.5 & 1.6 & 18.4 \\
\hline Worried & 11.5 & 2.6 & 38.7 \\
\hline Mad & 0.5 & 0.2 & 1.6 \\
\hline Otherł & 2.5 & 1.3 & 4.7 \\
\hline \multicolumn{4}{|c|}{$\begin{array}{l}\text { When your partner became pregnant with [child's name], did she } \\
\text { want the pregnancy then, want to wait or not want it at all? }\end{array}$} \\
\hline Wanted then & 70.8 & 88.8 & 16.5 \\
\hline Wanted to wait & 15.1 & 5.8 & 44.5 \\
\hline Did not want at all & 11.7 & 4.1 & 36.4 \\
\hline Don't know/no response & 2.4 & 1.3 & 2.7 \\
\hline Total & 100.0 & 100.0 & 100.0 \\
\hline
\end{tabular}

*The seven men who reported they did not know their pregnancy intention or did not respond to that question were dropped from these tabulations. HOnly one response was permitted. FIncluded frustrated, resigned, nervous, calm and indifferent. Note: na=not applicable.

cy among men, perceived discordance about pregnancy intentions between men and their partners, and evidence of inconsistency between men's intentions and behaviors.

\section{BACKGROUND}

El Salvador is a small country with a population of 6.5 million people, $45 \%$ of whom live in rural areas. Life expectancy is relatively high (about 70 years), and $80 \%$ of the population is estimated to be literate, although $21 \%$ of people live below the international poverty line. ${ }^{5}$ El Salvador is characterized by gender inequity that generally favors men socially, economically and politically, although progress is evident in some areas such as education. ${ }^{6}$ The country has had political strife for decades, and years of violent civil conflict finally ended in 1992.

Childbearing patterns in El Salvador have changed considerably in recent decades. The total fertility rate fell from about 6.3 children per woman in the mid-1970s to 2.9 children in the late 1990s. ${ }^{7}$ In the 2002-2003 survey, about $67 \%$ of married women aged $15-49$ said that they or their partner were using a family planning method; the proportion was similar in the national sample of men aged 15-59. The most common method used by women and men was female sterilization (reported by about one-third of all respondents), followed by injectables and oral contraceptives, and about three-fourths of women obtained methods from government health services. ${ }^{8}$ Unintended and teenage pregnancies are pressing reproductive health and social issues in El Salvador. ${ }^{9}$

\section{DATA AND METHODS}

The data for this study come from the El Salvador National Male Reproductive Health Survey, carried out in 2003 by the Salvadoran Demographic Association, with technical assistance from the Centers for Disease Control and Prevention. The first male survey of its kind in El Salvador, it included 1,315 respondents, reflecting an 80\% response rate among eligible men. Sampling was stratified by area of residence (Metropolitan Area of San Salvador, other urban areas and rural areas) and was conducted in multiple stages, whereby neighborhood blocks and then households within blocks were randomly selected. Within each household, one male resident aged 15-59 was randomly selected for a face-to-face interview with a male interviewer. The weighted data represent the reproductive-age male population of El Salvador.

Men were asked questions about their partner's pregnancies that had ended in live births in the five years preceding the survey. These questions tap into different dimensions of pregnancy desirability (Table 1). The first question was the conventional one used to determine if a pregnancy is intended or unintended (mistimed or unwanted). The other four questions assessed effort to avoid pregnancy, effort to get their partner pregnant, feelings about the resulting pregnancy* and perceptions of their partner's pregnancy intentions at the time of conception. Information on pregnancies that ended in miscarriage, stillbirth or abortion was not collected in this survey because birth histories are considered more accurate than pregnancy histories, given that some women and men are less likely to report (or in some cases to know about) pregnancies that ended in abortion or miscarriage.

In all, 425 men answered questions about 577 pregnancies that had occurred in the last five years and ended in live births. Analyses were restricted to the most recent pregnancy reported by each man.

\section{RESULTS}

From men's perspective, $75 \%$ of the 425 pregnancies were intended (Table 1). The remaining ones were unintended (13\% mistimed and $11 \%$ unwanted) or of unknown intendedness (2\%). Sixteen percent of all men who reported a pregnancy said that they had been doing something (i.e., using some method of family planning) at the time to avoid conception. A greater proportion of men with unintended pregnancies than of their counterparts with intended ones said that they had been doing so ( $46 \%$ vs. $7 \%, \mathrm{p}<.01$ ). These

\footnotetext{
*This was an open-ended question, to which men were asked to give only one response. The questionnaire included a list of options, with a slot for "other," that had been determined from the results of the pretest. Interviewers were not instructed to read the options aloud, but many did so to help respondents answer.
} 
cases represent failures of family planning, due either to improper use or to failure of the method itself.

Nearly three-quarters (72\%) of recent pregnancies occurred when the man was trying to impregnate his partner. As expected, this was the case for nearly all men (93\%) reporting intended pregnancies, but for very few men (7\%) reporting unintended ones. Overall, most men (80\%) said they had been happy when they found out about the pregnancy. As expected, 94\% of men with intended pregnancies had this emotional reaction. Notably, however, more than a third (36\%) of men with unintended pregnancies also felt happy.

As a group, men perceived women's pregnancy intentions as similar to their own; that is, $75 \%$ of men said they had wanted the pregnancy at the time of conception, and $71 \%$ believed that their partner had wanted to get pregnant (Table 1). However, in the companion survey of women, only $54 \%$ of women said that their most recent pregnancy ending in live birth had been intended.

At the individual level, the great majority of men believed that they and their partner agreed on pregnancy intention. Among men who said their last pregnancy had been intended, 89\% believed that their partner had felt the same way. Among men who said their last pregnancy had been unintended, $81 \%$ thought that their partner had agreed (Table 1). Two-thirds (66\%) of those who said their last pregnancy had been mistimed felt that the timing was wrong for their partner as well, and 65\% who reported the pregnancy as unwanted said that their partner did not want it either (not shown).

Overall, 20\% of men perceived that their intention regarding the last pregnancy and their partner's intention had been at odds (not shown). Among men who had intended their last pregnancy, 10\% thought their partner had not intended to conceive at that time or in the future. The level of perceived discordance was higher among men with unintended pregnancies (mistimed or unwanted), of whom $17 \%$ thought their partner had intended the pregnancy.

\section{DISCUSSION}

While exploratory, these data show some of the complexity of men's experiences with intended and unintended pregnancy, and highlight key issues in the prevention of unintended pregnancy in El Salvador. Almost half of recent unintended pregnancies that ended in a live birth were conceived when the couple (at least according to the male partner) was actively trying to prevent pregnancy. Counseling and services might have helped such couples avoid unintended pregnancy by improving their use of their current method or by providing them with information about more effective methods.

Conversely, more than half of unintended pregnancies were conceived when the couple was not trying to prevent pregnancy. These couples may have needed assistance in taking more active steps to achieve and clarify their childbearing goals. The same could be said for some of the men whose last pregnancy was unintended, but who had been happy to learn about it. This response may suggest that some men had not been strongly averse to the pregnancy, or had had ambivalent or neutral feelings about it. Some of these cases could also reflect men's retrospective viewpoint at the time of the survey; that is, some may have grown more positive as the pregnancy progressed or after their child was born.

The perceived discordance between men and women about pregnancy intentions, at both the population level and the couple level (according to men), provides further evidence of the need for interventions to improve communication between partners about fertility goals and behavior. This lack of agreement, especially the relatively higher proportion of pregnancies viewed as intended by men, may point to profound differences in men's and women's perspectives on childbearing in general. For example, men may want larger families than women do, and may feel less affected by the responsibilities of pregnancy and parenthood. Many development programs, including family planning and reproductive health programs, are increasingly trying to acknowledge and address relationship and gender dynamics in their services. This study indicates that by using information from men in conjunction with that from women —or, ideally, information from couples_family planning programs will be better able to help reduce unintended pregnancy in El Salvador.

\section{REFERENCES}

1. The Alan Guttmacher Institute (AGI), In Their Own Right: Addressing the Reproductive Health Needs of Men Worldwide, New York: AGI, 2003; and Salem R, Men's surveys: new findings, Population Reports, 2004, Series M, No. 18.

2. Salem R, 2004, op. cit. (see reference 1).

3. International Conference on Population and Development (ICPD), Programme of Action, 1994, <http://www.unfpa.org/icpd icpd_poa. htm>, accessed Dec. 15, 2004.

4. Associación Demográfica Salvadoreña (ADS) and Centers for Disease Control and Prevention (CDC), Informe Final: Encuesta Nacional de Salud Familiar FESAL 2002/03, San Salvador, El Salvador: ADS, 2004.

5. Pan American Health Organization, Core health data selected indicators, El Salvador, updated 2002, <http://www.paho.org/English/ DD/AIS/cp_222.htm>, accessed Dec. 15, 2004.

6. World Bank, El Salvador-Moving to a Gender Approach: Issues and Recommendations, Sector Report, Washington, DC: World Bank, 1996, No. 14407-ES.

7. ADS and CDC, 2004, op. cit. (see reference 4).

8. Ibid.

9. Padilla de Gil M, Aspectos médicos y sociales de la maternidad en la adolescencia, Revista de la Sociedad Chilena de Obstetricia y Ginecologia Infantil de la Adolescencia, 2000, 7(1):16-25.

\section{RESUMEN}

Contexto: En El Salvador, indicar que un embarazo no ha sido planeado es menos común entre los hombres que entre las mujeres. Sin embargo, las intenciones de los hombres con respecto al embarazo no se comprenden tan bien como sucede con las mujeres. Métodos: Para examinar las intenciones con respecto a los embarazos de sus parejas que terminaron en un nacimiento vivo durante los últimos cinco años, se analizaron los datos de 425 
padres que participaron en la Encuesta Nacional de Salud Familiar realizada en El Salvador en 2002/2003. Se les preguntó si habían estado tratando de evitar un embarazo en el momento de la concepción, si habian estado tratando de causar un embarazo, y también cómo se sentían con respecto al embarazo que resultó y cuáles habían sido las intenciones de su pareja con respecto al embarazo. Los análisis descriptivos se basaron en el embarazo más reciente que hizo mención cada hombre.

Resultados: Según los hombres, el 24\% de los embarazos no habian sido planeados_el 13\% habian ocurrido a destiempo y el 11\% no habian sido deseados. Casi la mitad (46\%) de los embarazos no planeados se habian concebido en el momento en que el hombre estaba tratando de evitar un embarazo. Sin embargo, el 36\% de los hombres que indicaron que el embarazo no era planeado señalaron que estaban felices cuando se enteraron del hecho. En el 20\% de todos los casos los hombres percibieron que su pareja habia tenido intenciones diferentes a las suyas con respecto al embarazo.

Conclusiones: En El Salvador, los servicios de planificación familiar y los programas de extensión conexos deben mejorarse y dedicar más atención a los hombres. Las experiencias de los hombres con los embarazos no planeados-en particular, con las fallas de la anticoncepción y el desacuerdo en las intenciones reproductivas entre la pareja-son complejas y ameritan un mayor trabajo de investigación.

\section{RÉSUMÉ}

Contexte: Au Salvador, les pères qualifient moins souvent les grossesses de non planifiées que les mères. Les intentions de grossesse des hommes ne sont toutefois pas aussi bien comprises que celles des femmes.

Méthodes: Les données relatives à 425 pères ayant participé à une enquête nationale de santé reproductive des hommes au Salvador en 2003 ont été analysées dans le but d'examiner leurs intentions à l'égard des grossesses de leurs partenaires ayant abouti à une naissance vivante au cours des cinq dernières années. Il leur avait été demandé s'ils essayaient d'éviter une grossesse au moment de la conception, s'ils avaient essayé de féconder leur partenaire, ce qu'ils avaient pensé de la grossesse et ce qu'avaient été, selon eux, les intentions de grossesse de leur partenaire. Les analyses descriptives reposent sur la dernière grossesse déclarée par chaque homme.

Résultats: Un quart des grossesses n'avaient, dans la perspective des hommes, pas été planifiées: 13\% étaient survenues à un moment inopportun et $11 \%$ étaient non désirées. Pour près de la moitié (46\%) des grossesses non planifiées, la conception avait eu lieu alors que le père essayait d'éviter une grossesse. Trentesix pour cent des hommes ayant déclaré une grossesse non planifiée se sont toutefois dits heureux d'en avoir appris l'existence. Pour 20\% de l'ensemble des grossesses, les hommes percevaient, de la part de leurs partenaires, des intentions de grossesse différentes des leurs.

Conclusions: Les services de planning familial du Salvador doivent être améliorés et des services et activités ciblant les hommes doivent être assurés. L'expérience masculine de la grossesse non planifiée (en cas d'échec contraceptif et de divergence d'intentions au sein des couples surtout) est complexe et mérite un examen plus approfondi.

\section{Acknowledgments}

The authors thank Lisa Whittle and John Santelli for their helpful feedback on this article.

Author contact: acq0@botusa.org 